\title{
An audit of referral patterns for glioblastoma patients in Beaumont hospital
}

\author{
J Clerkin \\ From International Conference for Healthcare and Medical Students 2011 \\ Dublin, Ireland. 4-5 November 2011
}

\section{Introduction}

This audit examined the referral patterns for newly diagnosed glioblastoma patients at a specialised tertiary referral centre, to uncover any intrinsic delays within the system. Differences in the interval for admission and surgery in relation to different referral sources and symptomology were analysed. Such delays negatively impact on patient care.

\section{Methods}

Medical case notes for 81 histologically confirmed GBM patients who underwent surgery in Beaumont hospital in 2010 were examined. Information regarding patient demographics, referral source, symptomology and dates of first presentation, CT scanning, admission and surgery were extracted.

\section{Results}

The median time from CT diagnosis to admission was 6 days, and 3.3 days for subsequent surgery. Variations existed between referral sources, with those presenting to $\mathrm{A}+\mathrm{E}$ with neurological deficits being diagnosed more promptly.

\section{Conclusions}

Newly diagnosed glioblastoma patients experience delays in accessing neurosurgical care with location of first presentation and severity of symptomology being the most influential factors.

Published: 9 July 2012

Royal College of Surgeons in Ireland

(C) 2012 Clerkin; licensee BioMed Central Ltd. This is an Open Access article distributed under the terms of the Creative Commons Attribution License (http://creativecommons.org/licenses/by/2.0), which permits unrestricted use, distribution, and reproduction in any medium, provided the original work is properly cited.
doi:10.1186/1753-6561-6-S4-048

Cite this article as: Clerkin: An audit of referral patterns for glioblastoma patients in Beaumont hospital. BMC Proceedings 2012 6(Suppl 4):O48.
Submit your next manuscript to BioMed Central and take full advantage of:

- Convenient online submission

- Thorough peer review

- No space constraints or color figure charges

- Immediate publication on acceptance

- Inclusion in PubMed, CAS, Scopus and Google Scholar

- Research which is freely available for redistribution Submit your manuscript at
www.biomedcentral.com/submit C BioMed Central 